\title{
Critical Readings of Joseph Conrad's Lord Jim
}

\author{
Ayila Orkusa \\ Ph.D. \\ University of Nigeria \\ Nsukka, Nigeria \\ johnmustardsafe@gmail.com
}

\begin{abstract}
There are much scholarly readings of Joseph Conrad's Lord Jim. This paper randomly picks some of the papers according to the various ways the scholars have studied the text for a review. Such critical readings have been examined here, considering the topical, thematic as well as theoretical and conceptual frameworks that have guided the studies. By so doing the paper answers the question on ways through which Lord Jim is read. The paper therefore shows that source study, reader response investigation, aesthetics analysis, modernist view, postcolonial readings, religious and moral approaches, stylistics, queer reading and other heterologous readings have dominated the scholarly works on Lord Jim. The conclusion is that these readings have assumed Lord Jim offers codes for interpreting society or life. Thus, most of the critics read the text as philosophy, while others read the texts as allegory or a testimony of the author or his society. But such interpretations have often offered a less clear view about the texts and as a result, many accuse the author of being obscured. However, few studies have approached the text as an art. The study remains important as it draws together many of these readings that have differently treated Lord Jim (literature) both as ideology, discourse, and art.
\end{abstract}


Keywords: Critical, reading, Conrad, Lord Jim

Introduction

Joseph Conrad's Lord Jim elicits wide reading in the literary circle and beyond, since its publication. And this paper seeks to answer the question on the various ways scholars engage the text. The detailed scholastic reading of Lord Jim have bring insights to the knowledge of the text. Sometimes the arguments seem contradictory, yet the literature on Lord Jim have shown the dimensions of reading a literary text in general such that by exploring them one can fully grasp the material, efficient, formal and the final causes of the text, as Aristotle shows on the four causes of art. Sometimes same theoretical or conceptual frameworks are employed to answer different questions on the text. This further supports the fact that the literary text can be approached from different angles for academic purpose. On the other hand, the various readings have shown that a literary text is like a fist with many fingers and it is to the advantage of literary scholarship not to pick one of the fingers to claim that it is the whole feast. Giving attention to the several ways Lord Jim is read brings out truth about the text.

Again, the setting of the text, the characters and some of the readings portray it as a prolific masterpiece for World Literature. The setting being Asia and most of the characters are Asian while the central characters are Europeans. Thus, a large body of works on Lord Jim devote to study postcoloniality from the text, and there is a popular attempt to label the text as a postcolonial text. However, the various readings have extricated Lord Jim from being label after any of the adjectives that precede the text: Postcolonial, Marxist, Philosophical, Sociological etc. but a literary text. The available literature on Lord Jim are therefore discussed here under the following subheadings: Source study, reader response theory examination of Lord Jim, aesthetics analysis, modernist view, postcolonial readings, 
religious and moral approaches, stylistics, queer reading and other heterologous readings. Nevertheless, suffice it to say that the critical works on Lord Jim are not exhaustively discussed here, but only some of works selected randomly for critical examination.

\section{Source Study}

Many critics have read Lord Jim as a testament on the life of the author or of his society. Some of such scholars read works of art looking for its source in the society. For example, in 'Conrad's Source for Lord Jim', Norman Sherry says that there has been an assumption that Conrad's Patna story in Lord Jim is based on an actual event, the desertion of the pilgrim ship S.S. Jeddah by her European Captain and Officers but the speculation remained vague and unsupported by evidence. Because Sherry himself shows that none of the crew, as far as is known, played the role which Conrad gave Jim. Nevertheless, Sherry maintains that it is the scandal in the Eastern sea that caught Conrad's imagination in Lord Jim (545). Sherry devotes his entire paper to prove that Conrad's Lord Jim is inspired by the real story of SS Jeddah, and Conrad is particularly motivated by the first mate of Jeddah at its desertion, Augustine Podmore Williams. Sherry presents excerpts from letters, condolence book, media reports and pictures to prove that the story of Jim is the story of A.P. Williams with little changes that Conrad employs to make his art. In his detailed analysis, Sherry combines sources to show parallels between Jim and A.P. Williams. He states that 'Conrad builds up his brief description of Jim's background by means of such precise details' (56). Sherry cites Conrad's Lord Jim side by side with the letter from A.P. Williams' family member below to prove his point. He cites the narrator saying:

He was an inch, perhaps two, under six feet, powerfully built, and he advanced straight at you with a slight stoop of the shoulders, head forward, and a fixed from-under stare which made you think of a charging bull. His voice was 
deep, loud, and his manner displayed a kind of dogged self-assertion which had nothing aggressive in it.... He was spotlessly neat, apparelled in immaculate white from shoes to hat, and in the various Eastern ports where he got his living as a ship-chandler's water-clerk he was very popular. (Sherry Qtd. Lord Jim 554)

Williams' powerful built and neat dressing, Sherry says, is confirmed when Mrs. Thornett replied to the question on such attributes. In her words:

I have read Lord Jim and it certainly does seem that reference is made to my Father \& the description in Chapter 1 seems typical. From my recollection of him as a child, he was powerfully built, very tall and had a deep voice, though gentle at heart. $[\mathrm{M}] \mathrm{y}$ father did dress carefully, very neat, all in white, I believe they were called 'tutop' the jackets were buttoned up the front to the neck.

Sherry also mentions the fact that Williams later in 1882 worked on the Vidar, a ship on which Conrad himself would become first officer from 1887 to 1888 . He says that in those years Conrad made some journeys from Singapore to Brow, in the Eastern Borneo on the Brow River, which was to become Conrad's source for Patusan in Lord Jim, and Sambir in Almayer's Folly and An Outcast of the Islands (555). Sherry argues that at Brow Conrad met some individuals that inspired his writings and Jim Lingard particularly whose Malay title 'Tuan Jim' provided Conrad with the title of his novel - Lord Jim. Sherry believes that Conrad must have heard of A.P. Williams from the first and second engineers of Vidar, James Allen and John Niven while he served on the Vidar and later then had met Williams as a Chandler's water-clerk in the port of Singapore (Sherry 555). Given these detailed resemblances between A.P. Williams and Jim, Sherry tries to make a case that Conrad's 
inspiration depended upon the story of S.S. Jeddah and A.P. Williams particularly as the source of $\operatorname{Jim}(557)$.

Marcus Wheeler's work also inclines towards source study in Lord Jim. He synthesises critics' approaches to Conrad and identifies elements of Polishness in Lord Jim in his essay 'Polonism in Conrad's Lord Jim'. Wheeler in his paper takes the position that, among all Conrad's works, Lord Jim is the one with the greatest appeal for Polish readers (6). Wheeler's work mentions areas of Polish influence on Conrad's Lord Jim, without developing full arguments on how such influences have affected Lord Jim as a text. He simply indicates some of the Polish influences on Lord Jim which include cultural background, literary devices, word order, and Linguistic features. He highlights some of the linguistic features like proverbial sayings and figures of speech; confusion in the use or omission of the definite and indefinite articles; confusion in the use of the past tense; erroneous prepositional usage or idiom; and idiosyncrasy in vocabulary as being the direct influences from Conrad's Polish background (6-7).

Reader Response Theoretical Examination of Lord Jim

Contrary to the above views, Amar Acheraïou in his book, Joseph Conrad and the Reader: Questioning Modern Theories of Narrative and Readership, examines the author figure (which Conrad himself represents) and reader relationship in the works of Conrad with a deft survey on narrative and readership theories. He affirms that 'Conrad's writing exemplifies reader-response theory, authorship, visual aesthetic and narrative form at large' (1). Acheraïou classifies Conrad's characters as nominal and the metaphorical readers, arguing that all the characters in Conrad's works are either nominal or metaphorical readers. He considers Jim as a nominal reader, who reads everything from newspapers to light literature and history, but remains a myopic, incompetent reader, tied to surface reading and 
literal meaning (94-5). In Acheraïou's view, Jim's reading, however impacts upon his professional conduct and philosophical worldview (97). Acheraïou asserts that Marlow on the other hand is a metaphorical reader like Heyst in Victory and Marlow in Heart of Darkness. He argues that Marlow's mediated narration of Jim's story displays a strong visual inclination (106). Acheraïou is of the view that Marlow is distinguished from the rest of the audience in the court room through the how-why dichotomy that divides the population of the text against Jim. Marlow is concerned with the fundamental why of Jim's jump in the Patna while the rest are preoccupied with the superficial how. Acheraïou holds that it is this how-why dichotomy that distinguishes Marlow as a metaphorical reader in Lord Jim (108). According to him, 'Marlow is not only a higher judging agency apt to evaluate deeply human experience, but also a rhetorical reader inclined to vertical reading, eager to see beneath the surface of texts and fact' (109).

Acheraïou explores Conrad's narrative technique, positing that Conrad's 'works are articulated around dual voice narrative,' breaking down linearity and epistemological unity to create a dialectical relationship between meaning and truth (110). This implies that Conrad's narrative technique is responsible for the ramifications in his works, and the narrative technique allows meaning to proliferate (110). Acheraïou acknowledges the presence of ambivalence in Lord Jim (118), but just like many other critics, his discussion eludes the study of ambivalence. He concludes by describing Lord Jim as 'an odyssey of reading... full of readers, fictional and metaphoric, and contains a profusion of listeners and audiences of various kinds' (190). He says the success of Lord Jim is in the fact that Marlow has finally found a highly valued reader, 'the privileged reader to whom Marlow sends a batch of letters' (190). 
Aesthetics Analysis

Yael Levin commits herself to the study of the origins of the otherwise-present representation of Jim in her book, Tracing the Aesthetic Principles in Conrad's Novels. Levin begins her work by making observations of critics who have read Conrad as being obsessed with impalpable presence (2) by the way he impacts his story with contradictions, a narration in which shadow, silence, darkness and the obvious markers of lack are given the power of presence. According to Levin, this effect lessens the distinction between absence and presence as 'the impalpable is conjured up, fleshed out, and transfigured' (3).

Given the foregoing, she is of the view that to be successful in the reading of Conrad, one must break away from the inexorable recognition through binary poles. Unlike Acheraïou who identifies how-why dichotomy in Lord Jim, Levin suggests, we must break from reading dichotomies in Conrad generally. In her words:

It seems that in order to address Conrad's writing, we must cast off not only the folk tale, but also the premise it shares with Western metaphysics. For in order to reread Conrad's absent presences and present absences, we must renounce the rigidly dichotomous and disjunctive view of the binary poles and transcend our inexorable bias toward presence. (5)

Levin calls for a rethinking of relationship by introducing a conjunctive approach as an intermediary. She concurs with Rachel Glenny on the position that Jim's dream world controls his reality. She also aligns with Jeremy Hawthorn's description of Jim as an idealist who replaces the physical world with his mental images such that his real 'world recedes before the wondrous imaginings of the mind' (Hawthorn 47). The consequence of this condition of Jim, Levin says leads to Jim's perception of reality, which is regulated by his imagination, and 'Jim sees otherwise' (24). Levin compares this experience of Jim with others of Conrad's protagonists like Almayer in Almayer's Folly and Willems in The Outcast 
of an Island whose imaginative thinking creates an illusory world for them (the protagonists), causing them to see otherwise (24-5). Levin holds that both Jim and these other protagonists are 'blind to what is and haunted by what is not' (25). According to Levin, the dynamics of Lord Jim go far beyond the similarities shared among other protagonists and Jim into ambiguousness that affirms the text's obscuring haze (26).

Levin studies the duality of Jim from different readings of Lord Jim, and submits that besides the otherwise present, Jim himself can be seen otherwise from who he is. 'Thus, as opposed to Almayer and Willems, Jim not only sees what is otherwise present, but is also seen as such' (26). Levin posits that seeing otherwise is Conrad's psychological method of making his protagonists grapple with the unbending merciless fate and at the same time the way readers should understand his texts. She examines the narrative style in Lord Jim and submits that Marlow's position as a narrator is ambiguously located. Because Marlow simultaneously recites incriminating evidence against Jim and as well appeal for his extenuation, a position which makes him oscillates between enemy and friend (29).

Levin further argues that Jim is not the only idealist, but Marlow the narrator himself is also an idealist. She supports this view by citing Edward Said thus:

Marlow's generosity toward Jim is rooted in precisely that same tendency to romantic projection because of which Jim so embarrassingly prefers courageous voyages in projective inspiration to voyages in actuality. Neither man, whether hearer or storyteller, truly inhabits the world of facts. (Said 1023)

In this way Levin shows that Marlow does not believe in facts, as it is typical of Jim (32). Levin holds that Marlow a reporting subject is also entrusted with an additional duty of an objective observer. So, his accounts 'are always already haunted by reverberating ambivalence' (32), but much more, it shows that 'the source of Marlow's inspiration is 
equally the source of angst' (35), insofar as he depends on the experiences of others for his source, because his narrative is filled with incertitude and indeterminacy. Levin reveals two characteristics of Marlow's narration that contribute to the elusive presentation of Jim as: his questioning methods and the content of his memory (36-7). Again, Levin observes from other critical readings of Lord Jim, Marlow's incapability to narrate Jim's story because such a task would compel him to 'address professional, psychological and ethical questions that he would rather repress' (38). Levin's study shows that Marlow's probing technique, Jim's status as a memory trace, and Marlow's own psychologically motivated evasions are some factors responsible for the otherwise-present representation of Jim.

She finally compares Marlow and Stein as both catchers of specimens. Through memory Marlow preserves the memory of his own specimen and brings it out in a form of narrative just as Stein does through the catacomb and glass encasings (46). Levin shows that Lord Jim ends with a presence that is evoked through writing, beginning from Jim and then Marlow. The full implication of this writing, she says, is the presentation of the absence that is expressed through presence. This absent-present Levin asserts, implicates the reader in the novel's action, and the reader's vision like Marlow's and Jim's are distorted. Thus, Levin is saying that "we can perceive only that which is otherwise present" (52).

\section{Modernist View}

Sandra Dodson on the other hand takes to the modernist view in 'Conrad's Lord Jim and the Inauguration of Modern Sublime'. She gives a panoramic view on Joseph Conrad and his modern fiction, arguing that it conveys a monumental failure of vision, a blurring of forms and outlines, a persistent obfuscation of symbolic meaning behind a dark and indeterminate representational or scenic surface (80). She compares Conrad with the romantic symbolists emphasising that the 'obfuscatory effect in Conrad's novels operates for the most 
part at both formal and thematic levels' (81). Dodson, however charges Conrad of being subversive and dialectical in relation to romanticism (81). Given such a general background of Conrad's works, she is of the view that Lord Jim is particularly opaque, which she says is a common feature of Conradian texts, and Jim's characteristic indeterminacy has not to do just with thematic or descriptive opaqueness in the text, but with the formal opaqueness of the texts as constructs in the language (82). Dodson submits that Lord Jim constantly foregrounds the mechanical process of Marlow's narrative, denying ontology of knowledge and authority (82). She maintains that though some critics have situated Conrad's fiction within the logocentric tradition or French symbolism struggle and have argued about Conrad's persistent reliance on strategies of obfuscation, such scholars could not account for Conrad's incompleteness of utterance or indeterminacy of meaning without subverting the symbolist notion of founding logos (83). She, therefore, distinguishes Lord Jim in her reading from what others have done. She attributes this distinction to Conrad's style, which is the combination of his (Conrad) modernity with his inauguration of the modern sublime in English fiction that 'draws the human subject inexorably into an allegorical web of discourse and interpretation' (85).

This argument implies the potential absence of a transcendent realm of meaning in Lord Jim. Dodson sees Lord Jim as having a philosophical implication of an individual moral crisis, and Jim's abandonment of the ship has a typological status of a fall and yet far from being an authenticating, the exemplary emblem of its biblical prototype (85). This fall, according to Dodson, is only authenticated in the biblical theology of Judo-Christian belief and if Lord Jim is first a typology of the fall, but not a biblical prototype then the subversion which Dodson sees as its purpose is ambiguous and juxtaposing. Dodson emphasizes Jim's transgression, but fails to state clearly what this transgression could mean. However, she asserts that: "The aesthetic significance of the fall becomes even clearer when we realise that 
Jim's transgression marks not only a fall into a sublime mode, but a fall out of a condition of specifically romantic mystification' (86). She is of the view that Jim's explanatory discourse, which constitutes a subtext for Marlow's narrative is characteristically elliptical, disjointed and incomplete, a stammer, which suspends meaning in the very motion of seeking it out (93). Her position here is that there are textual inconsistencies in Lord Jim and she argues that although Marlow takes a pivotal role as storyteller and interpreter in the novel, his own expository reading of Jim's narrative cannot solve its textual inconsistencies or provide the solace of closure. She says, '[Marlow's] narrative repeatedly announces itself as an interpretative exercise - the flawed product of conjecture and speculation, thwarted by the inadequacies of language and the opacity and elusiveness of its subject' (94).

Some of the issues we encounter in Dodson's reading are present in Tracy Seeley's reading as features of modernist text, but, to Seeley, Lord Jim has a surplus value. In 'Conrad's Modernist Romance: Lord Jim', Seeley points out that studies of Conrad's modernism invoke the isolation of consciousness, the indeterminacy of language and experience, philosophical scepticism and literary innovation (495). She warns that given the recent revision on modernism, readers should be wary of seeing either Conrad or Lord Jim as a modernist paradigm. Yet, she goes on to argue that Lord Jim is securely placed as a modernist text because of the disruption in chronology, subjective narrators, and thematic indeterminacy (495). Her position is that Conrad's modernism in Lord Jim embraces other streams like aesthetic, historical, philosophical, political, and personal, which are not all amenable to received notions of what counts as modernism (496); thus, to her, such form of modernism has a certain loyalty to romance. In her words:

'A Romance' describes the whole of Lord Jim, and not simply its tale of a hapless adventurer far from home, an unself-conscious romantic who wanders into that most exotic locale, a modernist novel. Here, I return to the quotation 
at the top of this essay, to suggest a connection between the generic designation 'Romance' and Conrad's modernism, a link suggested by his observation that it is both high tragedy and inestimable privilege for mankind to aspire to the impossible. (496)

In her explanation of what seems as a coalescence of impossibilities, Seeley says romance does not disappear in the twentieth century, instead a branch of it begins selfconsciously to recognize and attend to the impossibility of its own ideal aims. Seeley sees Lord Jim as a kind of romance that explores human aspiration, not simply to the ideal, but to the admittedly impossible, scepticism inherent in modernism (497).

She says Jim is in integrity romance; he wants his ideal self to be identical with his real self and 'this becomes his utopian romance goal'. Jim does not despair because of his ego-ideal. Thus, Seeley agrees with Stein calling Jim 'romantic', 'Jim is romantic as Don Quixote is romantic', and there is no difference between his naiveté and being romantic. But on a whole, reality becomes unfriendly for his imagination to turn real. Seeley points out that Marlow has seen and recognizes Jim's romance: the distance between Jim's desires and the world. The impossibility of the desires and the real to reconcile leads to a failure that Jim fails to admit. Though Marlow tries hard to bring him into the community that depends on the ideal and disillusionment, Jim remains an outsider for not acknowledging his disillusionment. Seeley submits that Marlow speaks like a modernist romance narrator, assessing the futility of his task. Finally, Seeley like Dodson concludes that 'in Lord Jim there is neither transcendence nor despair' $(498,499,508)$.

Whereas Seeley appears to synthesize the romantic ideals and the modernist in her reading of Lord Jim, what is synthesized in Harry S. Epstein's reading is tragic and the ambiguous in Lord Jim. Epstein affirms in 'Lord Jim as a Tragic Action' the presence of ambiguity in Lord Jim, and he says that such ambiguity reflects the system of probability 
operating in the universe of the text, which is neither hostile nor friendly but unpredictable (230). Epstein is of the view that the occasion of ambiguity in the reader's judgement and the system of probability form the substance of the book, which is obvious from the opening pages (231). Epstein makes an argument that the ambiguity in Lord Jim is governed by a tragic power. In his words:

The attempt to make a tragedy of a tale premised on the ambiguity defined by Van Ghent demands our attention because the ambiguity does not reflect Conrad's merely private concerns. The moral universe of Lord Jim includes skeptical assumptions about order in the universe and materialistic assumptions about the human psyche. These two sets of assumptions are the roots of modern man's ambiguous understanding of human responsibility. Hence the novel reflects modern man's dilemma: the community, in order to function successfully, must assume that individuals are responsible for their acts, while the individual can be coerced into actions he has not chosen by pressures beyond his control. (231)

Epstein is saying that the assumption order in the universe and materialistic assumptions about human psyche are the source of the modern man's ambiguous understanding of human responsibility. So, for Epstein, Lord Jim reflects the modern dilemma, explaining for the health of the community, which can hold individuals responsible for their acts, but these individuals on the other hand can be pressurized into actions beyond their control. Thus, Epstein argues that the tension between Jim's moral disposition and psychology provides the potential for his tragic significance (232). Jim's sensitivity to personal honour and heroism led him to accept the community's code of responsibility, which made him want to stay in Patna. But his will fails him, even though he had chosen to submit and live as the code dictated. The reason for this, Epstein says, is because his conscious will 
mastered by urging, he could not control pushed him to violate the code which sustains his self-image. This failure of Jim according to Epstein, is 'man's potential failure', so it 'arouses terror, and because he suffers genuine anguish at the recognition of his failure, he becomes the object of reasonable pity' (232). Epstein holds that what gives Jim his tragic significance is the structure and the narration of the action which brings him to his doom. Epstein points out that the narration of the first part of the text creates a dramatic scene and this scene gives the novel its tragic strength it shows 'Jim's psychological disposition and his liability to the pattern of failure and resolve which dominates the rest of the book' (233). He further argues that the tragic action of Lord Jim is conditioned by a clearly perceived and delineated ethical ambiguity (234). Epstein adds that comparison among several of Conrad's characters like Marlow, Stein, Chester, Gentleman Brown and many others can help to establish and shape the readers' 'response in preparation for the novel's tragic effect' (236). He is of the view that Jim's rejection of suicide as an alternative to his suffering marks the beginning of the final repetition of the tragic pattern (238).

In Epstein's view, even though Jim grows into a tragic figure, his situation cannot be compared to a conventional tragic hero, because Jim's jump from the Patna is not a tragic choice but an action out of compulsion. So despite the fact that the jump led to Jim's unhappiness, it does not sufficiently count as a tragic act since Jim does not really fall from good fortune (238). It is rather through Jim's decision to redeem himself that Conrad has endowed his doom with tragic significance and the good fortune he attains at Patusan rather provide a higher ground for a more 'conventional fall to bad fortune to take place; and when we see that the fall is occasioned by Jim's continued commitment to choose virtuous action, it takes on a peculiarly intense tragic significance' (239). Epstein adds that Jim's success at Patusan brings him to a position that clearly displays the tragic features, and as we can see, when the catastrophe happens everything that gives Jim happiness is destroyed. Epstein 
concludes by saying that the form of the novel is fulfilled by the presence of the tragic power. However, for the fear of the compromise of the reader's experience of the conclusion, which may weaken the tragic power of the entire novel, Conrad decides not to end the novel with the death of $\operatorname{Jim}(243)$.

\section{Postcolonial Readings}

Robert Hampson takes a postcolonial view in his study on Conrad. He devotes a chapter of his book, Cross-Cultural Encounters in Joseph Conrad's Malay Fiction to Lord Jim stressing the importance of gossip, also known as 'after dinner narrative' (130), and how it helps in structuring Lord Jim as a text. He says Jim's jump, for instance generates criticism among the colonised people and 'serves to undermine the European position of authority' (131). Hampson holds that Marlow is also a part of this gossip community as he tells the story of Jim, but 'he presents his gossip as anti-gossip through the invocation of models of privileged information' (132). But far better than others, 'Marlow's gossip is of the type that provides opportunity for self-disclosure and for examination of moral decisions' (134). Hampson speaks of competing narratives and repeated narratives and above all the contrasting patterns which 'emphasise the male inheritance of power, the female inheritance of suffering, and Marlow's subordination of non-European priorities of Jim's place among the competing narratives' (136). Hampson argues that Jim's story in Patusan quickly turns to the folktale and legend myth. This 'legend implicitly offers an alternative narrative interpretation of Jim to Marlow' (136). The myth and legendary story of Jim is soon replaced by the politics of rumour which comprises Cornelius's gossip on the local politics of Patusan, the quest to understand the purpose of Brown's visit, the problems of Europeans' visit, the politics of the Burgis and the Malays (142-3). He observes that after a careful observation of the cultural conflict among the Burgis, Malays and Europeans, and their interpersonal 
relationship, Hampson concludes that Conrad produces in Lord Jim 'a colonialist discourse but works to problematise that discourse both through objectifying it and through acknowledging the existence of their histories and other cultures' (145).

Following Hampson's colonial reading of Lord Jim, Padmini Mongia in his 'Narrative Strategy and Imperialism in Conrad's Lord Jim 'holds that the story of Jim as Marlow tells it is deeper than how Marlow understands it. The story is not a mere sea men's affair as Marlow thinks, but it concerns the relationship between colonizer and the colonized (173). Mongia is of the view that instead of addressing the racial issue on the Patna, Marlow focuses on the relationship between duty and character. For Mongia, imperialism creates enough material conditions for Marlow to engage the state of man's soul in Lord Jim. In this case 'the colonial situation in the text remains a backdrop for the narrative's interest in the modernist condition of fragmentation and isolation' (173). He argues that the complex narrative structure deflects action away from the plot and towards the process such that the apprehension of meaning becomes difficult. He considers this as a positive impact of the text. (174). He observes that after the transition in the narrative, though the omniscient narrator has introduced Marlow, bestowing on him the credibility to narrate Jim, Marlow struggles to interpret Jim 'because that struggle allows Jim's jump, and its possible commentary on imperialism, to recede into background' (176). Mongia accuses Marlow of blurring the social contours of the incident which is the origin of his interest in Jim through his narrative (176). He draws our attention to the letter Marlow wrote to one of his listeners, saying that Marlow does not perceive Jim as a colonizer, so in that letter if Jim is anything, he is one of the colonized as Marlow has also said in the letter that Jim although the leader was a captive in every sense. Because, the population and anything good around Jim, even the friendship and the love shown to him, were mere jealous guardians of his body. 'Every day added a link to the fetters of that strange freedom' (Lord Jim 188; Mongia 178). Contrary to this view of Marlow, Mongia insists that 
Jim plays a role in colonization like Stein and the privileged man to whom Marlow sends the letters. The only difference between the two who are also romantic as Jim is that, they have had accepted their position in trade and colonization, while Jim apparently did not consciously take a position in colonisation. Rather, 'his role is made non-specific, but the alliance between his own romantic project and the more material projects in which the two older men have been engaged indicates that Jim's metaphysical yearnings are analogous to dreams of empire'. (178)

Mongia further compares Jim to Stein, arguing that when Marlow needs help for Jim, he turns to Stein and Stein diagnoses Jim probable to be romantic and according to Stein, the only way to cure Jim requires the imperialist backdrop in Jim to find expression. 'His urge for heroic fulfilment can only be satisfied once he becomes Stein's agent in Patusan. None of the "opportunities to earn his bread" that Marlow has created earlier appease Jim's desires' (Mongia 179). Mongia holds that it is an impossible task to separate romantic urges from imperialist ones in Lord Jim, adding that 'All understanding of Lord Jim is finally conceived of in terms of tropes of imperialism' (179). For the role Marlow plays in his narrative, Mongia describes him as an artist of imperial myth (180). However, Jim's death points out that Jim removed himself from his specific role as colonial agent and becomes untainted, isolated in part by his immense capacity for dreams to die according to a heroic code (182).

Patusan, Mongia says, is described as the world of romance, whose historical specificities are denied portraying it simply as the stage upon which Jim's heroism can be played out. Mongia concludes that the narrative apparatus of Lord Jim is filled with the imperialists register that is essential to the story of 'acute consciousness of lost honour' (183).

Douglas Kerr takes a slightly different approach to look at colonialism in Lord Jim. In his essay 'Crowd, Colonialism and Lord Jim', Kerr uses technical terms to explain models of leadership as it relates to colonialism in Lord Jim. Kerr takes account of the people existing 
in Lord Jim (saying that Jim appeared) among the five white officers, the Malay crew, the eight hundred passengers, the crowded court, the bustling seaports and the unnumbered crowd at Patusan to draw our attention to bustling population the Orient featured in Lord Jim, even though from the beginning of the text, attention is drawn to see Jim alone standing apart from others' (49). Kerr observes that this bustling population of the East in Lord Jim is to the West a gigantic resource to be harnessed and gigantic danger to be controlled by few Europeans. Kerr says:

The oriental crowd was the focus of the most urgent anxiety of colonialism, an anxiety present in an extreme form in De Quincey, but visible everywhere in colonialist writing, and not least in those adventure stories for boys that so frequently have a scene in which some plucky hero faces down, outwits or in some cases converts a hostile - often fanatical - crowd. (Lord Jim itself is an intertextual changeling to this genre.) The human space of colonial Asia was the theatre of a grotesque disproportion - perhaps gratifying, certainly alarming - between the subject peoples and their colonial masters. The anxiety of outnumbering is not hard to understand in the imperial circumstances. (51)

Kerr compares the vast population in Lord Jim with that of Kipling's Kim and submits that 'the vast population in the East provides the West with an opportunity for a bit of sport. The Patna, for example, becomes a symbol of the theatre of colonialism where Jim stands out alone "contemplating his superiority"' (Lord Jim 2; Kerr 54).

Kerr draws from the Nineteenth Century crowd theory (which holds that a group's mind could be collectively surrendered to a leader more completely than any individual submission) (54), to show that by Jim's performance of trustworthiness as he spaces above them, the pilgrims stake their faith on the white officer. Putting their confidence in Jim because his 'theatrical' pacing about on the ship (54). Kerr points out that this pattern of 
winning other's confidence is again re-enacted by Jim in Patusan. And there at Patusan he always stands out as a white leader among the natives. He achieves 'the conquest of honour, love, men's confidence' (Lord Jim226; Kerr 55), on credit, through what Marlow calls his 'racial prestige' (Lord Jim 361; Ker 55). Jim stands out, a white figure among 'a group of vivid colours and dark faces' (Lord Jim 379; Kerr 55).

Kerr's reading of Lord Jim portrays Jim as wielding power over Patusan through his theatrical display, which manifests as Jim finally fails, and dies. For Kerr, even at death Jim raises a figure of colonial anxiety (55). The Asian Crowd in Lord Jim, for Kerr is a dormant or stagnant crowd over whom the representatives of distant Europe ruled. Jim for instance ruled over the Asian crowd both in Patna and Patusan through his 'racial prestige' (58).

Kerr also uses the concepts of hypnotism and suggestion to explain the source of Jim's fascination over the Asian population (58). He says hypnotism provides a model for the unconscious behaviour of crowds (58), so the crowd in Lord Jim is 'essentially unconscious, in a state of fascination akin to that of hypnosis' (58). Kerr associates the docility of Patna pilgrims beneath Jim's gaze to religious inclination, but the late submission of the population of Patusan to Jim's personal authority demonstrates Jim's hypnotic power. He supports this position drawing our attention to the fact that though the Patusan population had everything to defend itself, but it failed to take any decision when the boatload of pirates invades the river. The population in the absence of Jim remains 'helpless and inert as the hypnotized, believing themselves to be without a leader, they are suspended in political paralysis, waiting for Jim to return and tell them what to do'. (60)

In Kerr's view, hypnotism plays the greater role in Jim's relationship with the Patusan crowd. But in general, 'It is a species of fraud that guarantees the authority of colonialism over its Asian populations in the East of Lord Jim. Confidence - lost, restored, shared, abused - is one of the profoundly serious themes of the novel' (61). Kerr sums it up that it is not only 
the Asian crowd that is hypnotized but Jim too. He is 'Fascinated by the gorgeous virility of his dreams of far-flung heroism, he relaxes (perhaps disastrously) on his watch on the Patna, full of "a pleasurable languor" (62). The implication here is that in Patusan Jim leads his life unconsciously and instinctively.

Whereas Kerr's reading of colonialism is anchored on crowd theory, Sanjay Krishnan is interested in colonial space and movement in Lord Jim. In an essay entitled 'Seeing the Animal: Colonial Space and Movement in Joseph Conrad's Lord Jim' Krishnan examines the role of the Malays at the helms in the Patna and compares their capacity and incapacity to act with 'animal's relation to the world' (328).

Krihsnan notes a hierarchy and a divide separating the European and the native consciousness in Marlow's narration of Lord Jim, pointing out that whereas the German Captain and the second engineer of the Patna who are considered less thoughtful still have the capacity to evaluate and judge, but the Malay helmsmen do not possess this consciousness (328). He thus says: 'Like the animal, the Malays lack the faculty of imagination' (329). Krishnan draws our attention to the senseless 'immobility' of the steersmen at Patna and that of historical 'immobility' of the population at Patusan, saying that the immobility of the helmsmen refers to an incapacity for autonomous reflection while that of the population at Patusan is because of 'the absence of progressive temporal development' (329). Krishnan observes that Marlow sees the Malay as inferior humans who cannot be considered historical beings.

Krishnan further argues that through the natives' lack of ability to reflect, Jim's 'inward' being is enriched; so, the belittling of the Malays becomes necessary since it serves to illuminate human condition (331), and it is quite ironic that the value added to human beings is enabled by the exploitation of the natives as animals. He re-echoes Andaya and Andaya to support his argument on the historical setting of the natives' world in Lord Jim as 
it evokes the memory of British officials in colonial Malay in the Nineteenth Century. Krishnan therefore, tasks his readers to evaluate Marlow's narrative by a view of subjective interiority as the condition of historical civilization.

Again, he notes that, animals are not used in Lord Jim to secure only the superiority/inferiority relationship between European and the native existence, but it also interrupts Marlow's narrative in quite extraordinary ways' (334). In this case, the interruptive effects of the animal result in a revaluation of the relation between narrative and colonial subjectivity in the novel (334). Krishnan argues here that:

The associations that gather around 'buffalo' momentarily turn Marlow's narration in an unfamiliar direction, much as the word 'cur' disoriented Jim earlier. Like the dog that interrupts Marlow's narrative, the figure of the animal interferes to claim an active part in the staging of the scene. The two parallel worlds - European-human, native-animal - appear by this juxtaposition of sights and sounds to communicate or transmit something back and forth. (337)

The effect of the above, Krishnan says, is the pluralisation of Marlow's voice, giving the readers multiple perspectives that disrupt Marlow's authoritative interpretation (337). Krishnan says that the yellow dog provides new ways of interpreting Lord Jim, stating that it enables us to see how the movements in the native world are not without meaning.

These animal movements offer an insight into how a different conception of value can begin to emerge in the text, which is to also say that they suggest a different way to imagine 'the human' (339). Animal in Lord Jim according to Krishnan, suggest similarity between Jim and the Malays in that 'like the Malays, Jim is overcome by blankness and immobility that is not amenable to the representation demanded of him later by the court' (340). He says that 'the uncanny parallel with the Malay-Muslim pilgrims is first suggested when Jim breaks 
with the script of his own initiatory rite of passage into a community of European merchant seamen with his leap from the Patna' (346). On the other hand, Krishnan draws our attention to Jim's arrival at Patusan where Jim is depicted as an autochthon, born from the mud of Patusan (during his escape from his captor). After this event and all that followed, Jim cannot be considered as a European white on the civilizing mission (347).

Religious and Moral Approaches

Mathew G. Condon employs religious parlance to answer the question about the sacramental world in Lord Jim. In his paper, 'The Cost of Redemption in Conrad's Lord Jim', Condon holds that the question of the sacramental world is largely neglected by the critics of Conrad's Lord Jim (136). To this end, he chooses to foreground Jim's confession, the confession that allows him to disclose the Patna incident as he takes responsibility, but would never be absolved till his death in Patusan. Condon says that Jim clings to his crime and makes it an instrumental feature of himself while at the same time he insists on his 'innate blamelessness' (136). Thus, Jim does not receive forgiveness from Marlow nor does he forgive himself. Because of this lack of forgiveness, Jim's confession does not meet its fundamental aim which is redemption.

Condon makes an essential argument here in relation to the story, discourse, and plot, which answer the questions: what, how, and why (facts, events, and causes) respectively. He emphasises that why and how are mediated by the narrated episodes produced by what. And confession is concerned with facts, events and causes. Condon points out that in Jim's double confession the fact of an action obscures the immediate cause or motive of the action (137). Condon says Jim's offence that haunts him in the text is his breach of sailors' unwritten code of placing passengers' safety before the officers'; that jump in Patna as its first mate. This leads to Jim's acute consciousness of loss of honour (139). 
On the account of why Jim's confession fails to absolve him of his guilt, Condon says, one, Jim chose an ill-fit receptacle of his confession, Marlow. And two, Jim's father's 'easy morality' as captured in his father's letter has been discovered by Marlow. Such letter Condon says makes 'hope for absolution impossible' (141). But more profoundly, Jim never confesses why he jumped therefore he cannot be redeemed despite his confession of the fact of the action. Condon maintains that confession aims to relocate man from his marginalized position back into society, but it is not so for Jim. His 'failure to confess' leads him to selfexile and when he has again failed in that exile position he had no society to go back to, so he walks up to his death (143).

From the moral approach to literary art, Craig Taylor views Lord Jim as the type of literature in which 'our conflicting emotional responses to the narrative really suggest different ways in which we might fill it in' (79). In his essay 'Literature, Moral Reflection and Ambiguity', Taylor examines Lord Jim and submits that Jim's character remains ambiguous to Marlow and the reader, citing Marlow as saying, 'the idea obtrudes itself that he made so much of his disgrace while it is the guilt alone that matters. He was not - if I may say so - clear to me. He was not clear' (Lord Jim 135; Taylor 81). Taylor says that Jim remains ambiguous, even after his seeming achievement at Patusan. Jim seems not to have come to terms with his past, neither does he master it. After considering what Jim says to Marlow about the impossibility of forgetting his affair in Patna, which keeps haunting him despite his great success at Patusan (82), Taylor raises the following questions about Jim which are left unanswered. 'Has Jim really come to terms with or mastered his past weakness, is he really any more self-aware, or does his life in Patusan merely sustain his grand illusions about himself?' (82). Jim goes down to meet dreaming instead of fighting as Jewel begs him to stand and defend himself attracts such similar questions from Marlow. Taylor probes further requiring to know the significance of Jim going out to meet Doramin, 
and his refusal to fight as his wife would want him to do. These acts raise throbbing questions that remain unanswered even by Marlow who narrates Jim. And as such, Jim remains inscrutable from the beginning of the novel to the end, first to the narrator (Marlow), then to the readers. Taylor therefore holds that we cannot take the repeated phrase, 'He is one of us', to mean that we or the narrator have understood Jim (84). Rather, Jim's final act remains ambiguous and the text 'is hardly amenable to such attempt at resolution' (86-7).

Taylor argues that Jim represents a destructive fate for us all and trying to make Jim clear and unambiguous may not lead us to finding the truth, but rather insulates us from such type of fate that Jim represents (86). But there is no possibility to separate ourselves from Jim given the ambiguity and doubt around the text. Taylor says unfortunately there have been commentaries about the text that suggest 'an attempt to establish this kind of distance' (87). Taylor agrees to the fact that an engagement of literature can deepen our moral sensibility, but a text like Lord Jim can create gaps that exist for us in that moral sensibility. In his words: Lord Jim reminds us that we can never be entirely sure of ourselves, "since the truth can be wrung out of us only by some cruel, little, awful catastrophe". It is the part of what it is to have a developed, we might also say mature, moral sensibility that we do not discount the possibility that faced with such a catastrophe we might fail the test; a real sense of that possibility is itself I suggest a part of learning to think. (87)

Given the foregoing, Taylor posits that moral character is much more fragile than we can commonly like to believe (87). So, through our conflicting responses to literary works like Lord Jim we can gain a sense of what serious moral reflection requires of us. But 'A failure to subject ourselves to this kind of scrutiny is itself a kind of evasion of serious moral reflection and judgment' (89). It also reveals that Taylor has understood the risk of seeking for moral instruction from literature as he holds that 'Moral reading of Lord Jim may obscure 
our understanding and appreciation of this novel' (89). Taylor cites Peter Lamarques to support this point thus: '[t]o read philosophy is to read for truth. In contrast, to read and value a work from a literary point of view seems quite different ... literary works that are too obviously didactic, that too obviously are trying to impart a message, are seldom valued highly' (Lamarques 253-4). Taylor does not rule out the fact that literature might convince us of important truths, just as Lord Jim has done, but he is against the overt claim of a didactic nature of literature.

\section{Stylistics Approach}

James Chandler does a study on form in 'On the Face of Case: Conrad, Lord Jim, and Sentimental Novel'. He begins his study with the history of case form and the novel form. He draws our attention to the word case which at one point refers to Jim's problem and on the other refers to the container housing the beetles and the butterflies, which Stein fixes his gaze on while Marlow tells him about Jim. Chandler argues that Conrad's use of case in Lord Jim is deliberate and it serves as a metonymy which alternative readers may ignore (844-5). He points out that, 'the language of case and remedy cast Jim's case in medical terms and thus also frames the exchange between Marlow and Stein as a kind of medical consultation' (845). Chandler had at the beginning of the paper expresses what used to be his reservation for the use of the word case, but in the reading of Lord Jim he sees the phrase 'Jim's case' not as being pleonastic (846). Rather, he sees it as a framework of metaphors and metonymies that structure the central episode of Marlow's meeting with Stein, and it is an episode that ramifies the novel (846).

Chandler identifies style in Conrad which manifests in Lord Jim as well as other of his works. He notes that Conrad often deploys symbolic motifs to serve both as themes and figures of speech, which case and jump or leap are a common case in point in Lord Jim (847). 
Jump, Chandler says is more than a theme, but becomes a performative narrative trope in the novel (848). Because:

The trope or topos of jumping is not only crucial to Lord Jim but is also associated with the case figure by way of its association with the language of falling_Fall being the German for 'case', as Conrad would surely have known. Yet the case figure itself stands out among this group of tropes-cumtopoi in the novel. This is partly because of its conceptual and historical richness, on which Conrad demonstrably draws, and partly because of its importance to the history of the modern novel. (848)

Chandler further explains that case figure stands out among this group of tropes-cumtopia in Lord Jim for two reasons: one, because Conrad demonstrably draws on its conceptual and historical richness and two, 'because of its importance to the history of the modern novel' (848). Besides the emphasis on the importance of case to the history of the novel, Chandler shifts attention to the narrative structure of Lord Jim, which according to him is palimpsestic in nature (848).

Again, Chandler points at the instances of sentimentalism in Lord Jim, referring to the way Marlow shows interest in Jim. He also says that the device by which Marlow is introduced into narration constitutes a crucial sentimental structure (857). He concludes that the combination of Marlow's narrative and his interest in Jim defines Jim's situation as 'a case in the sentimental frame of reference' (859). Chandler therefore, describes Lord Jim as combining the language of the case and sympathy which elicit critical comments from critics.

Queer Reading

Jeremy Hawthorn uniquely differs from all the studies on Lord Jim here present, as he devotes his study to sexuality. In Sexuality and the Erotic in the Fiction of Joseph Conrad, 
Hawthorn asserts that Conrad's fictions subtly engage the subjects of sexuality and the erotic, and Lord Jim particularly has the traces of homoeroticism. Hawthorn supports this view by citing Richard J. Ruppel to prove that Conrad's stories are full of the representation of homosexual urge. He says Jim particularly, though sexually passive is desired by both Jewel and the mill owner for whom Jim first worked after the Patna incidence as well as Marlow himself (45). Hawthorn again points to the letter of Denver to Marlow, in which Denver appreciates the person of Jim. In this letter Hawthorn traces some expressions which show that Denver 'experiences sexual desire for Jim' (46). Hawthorn's claim that Marlow too has homoerotic desire for Jim, has no verifiable proof so long as it depends on Lord Jim. We simply read him as saying 'But what of the claim that Marlow too experiences homosexual desire for Jim?' (46). Then he goes on again to cite Ruppel referring to a different text than Lord Jim.

Richard J. Ruppel also argues that the relationship between the harlequin and Kurtz presents the most obvious example of same-sex attraction in Heart of Darkness. The harlequin is devoted to Kurtz - as his conversations with Marlow amply reveal. 'They had come together unavoidably,' Marlow explains, like two ships becalmed near each other, and lay rubbing sides at last. (Hawthorn 46-7)

Hawthorn's claim about homosexuality in Lord Jim remains unconvincing as Hawthorn himself seems to depend on Ruppel to prove his evidence. Moreover, Hawthorn somewhere else quotes Ruppel as saying 'the only absolute unequivocal homosexual in Conrad's fiction is the evil Mr. Jones, the antagonist in Victory' (Ruppel, 157). Given the above submission, it is difficult aligning with Hawthorn that the forms of sexuality in Lord Jim include homoeroticism. 
Heterologous Readings

There have been heterologous readings and reviews of Lord Jim as captured in the remaining part of this review. In 'Lord Jim's "Reward”: An Allusion to The Tempest', Ernest W. Sullivan highlights the connection between Conrad's works and that of Shakespeare. He submits that Jim is Conrad's evocation of Shakespeare's Prospero in The Tempest. After showing some resemblances between Lord Jim and The Tempest, Sullivan cites Conrad correcting his reader's fancy that Jim is an evocation of Prospero. 'Your fancy is most kind, but I fear it is a far cry from Prospero's Island to Patusan' (Sullivan 27). But Sullivan is of the view that though it may be a far cry from Prosporo's Island to Patusan but there are some shared details between Jim in Lord Jim and Ferdinand in The Tempest. Sullivan draws attention to the pre-nuptial lecture to Ferdinand by his father-in-law in The Tempest and Marlow's musing on the significance of Jim 'to touch his reward with "clean" hands to obtain a lasting reward' in Lord Jim. He, by this comparison holds that there is a literary allusion in to The Tempest in Lord Jim (27).

Sullivan's comparison between Jim and Prospero highlights a moral lesson, which he says reminds the readers of the fall in the Garden of Eden that brought man the reward of thorns. And like Prospero's pre-nuptial lecture to Ferdinand, to have 'satisfactory reward, Jim must consummate his opportunity with hands cleansed not only of the Patna desertion, but also of subsequent errors of judgment in Patusan, his current Eden' (28). Sullivan submits that the image of clean hands here adds to the moral ambiguity of Jim's reward because, for him 'at the moment of Jim's death, it is not clear that his hands are clean, only that they are empty' (28). But worthy of note here in the allusion; Sullivan says unlike Ferdinand, Jim could not fulfil his responsibilities and he did not receive his reward, the opportunities that were there waiting for him. 
Suresh Raval, after a review of some critical works on Joseph Conrad, asserts in his essay, 'On Reading Conrad', that criticism of Conrad's novels should not be 'reduced to scepticism verging on utter futility and despair', rather such criticism be 'seen in terms of the radicalism of its confrontation with hope and failure' (448). Raval holds that the originality of Conrad's scepticism resides in this confrontation and the success of the scepticism is not from its philosophical stand, rather its success is 'from the way in which its projections are concretized in language, action and character' (448). So interpreting Conrad is not a matter of focusing on philosophical ideas because, to centre the interpretation of Conrad on philosophical ideas would lead to a wrong judgment (446).

Raval observes that there is a profound accommodation of Romanticism, Greek tragedy and modernism in Conrad's novels; however, some available criticisms of Conrad have not come to terms with these profound ideas. He is suggesting that to achieve the task of coming to terms with the profound ideas in Conrad, there should be a perfect synergy of rhetorical criticism and philosophical criticism, where their various identities are lost into the new synergy 'but in seeking to show a complex and ambiguous yet powerful relation between art and sincerity' (448).

In 'Impression of Joseph Conrad's Lord Jim', Rachel Glenny says Conrad builds human psychology into his characters in Lord Jim, particularly Jim who catches Glenny's fascination. Glenny sees Jim as indulging in romantic dreams without appropriately adjusting to reality. She thus accuses Jim to have dulled his senses by allowing himself into wandering imagination which prevents him from coping with crisis (9). She sympathises with Jim after his desertion of the Patna and his trial (9).

For Glenny, Jim has adjusted to reality after the Patna incident. Jim has become firmer and adjusted to reality as he seizes the Patusan occasion with admirable firmness and at the end he dies vindicating what Marlow at the beginning calls 'a fixed standard of 
conduct' (10). Glenny's position here contradicts what Stein tells Marlow about the nature of Jim as a romantic.

Robert W. Trogdon in 'John Dos Passos on Lord Jim' reviews J.R. Dos Passos's reading of Lord Jim. He says that Passos unlike several other critics of Lord Jim is concerned with how Conrad is skilful at handling plot, his adeptness in switching point of view and his creation of characters that 'emerge with vivid distinctness' (99). Trogdon observes that it appears Conrad finally exerts a great influence on Passos's fiction at the level of narrative method that he learned from Lord Jim (100).

\section{Conclusion}

Scholarly studies on Joseph Conrad's Lord Jim have focused on such issues as society or source study, imperialism or colonialism, morality, religion, psychology, modernism and several other themes. These approaches have been used also to analyse Joseph Conrad's other works like Under Western Eyes, Chance,Heart of Darkness, The Mirror of the Sea, Nostromo, Notes on Life and Letters, The Nigger of the Narcissus, The Secret Agent, Victory,Typhoonand Other Tales.

The recent and the less recent scholarly works on Lord Jimhave been studied and the observation is that the early studies seek to interpret the texts; to extract a definite meaning from the texts. There is a general assumption that Lord Jim offers codes for interpreting society or life. Thus, most of the critics read the text as philosophy, while others read the texts as allegory or instrument to understand the authors' past. But such interpretations have offered a less clear view about the texts and as a result, many accuse the author of being obscured. Few readings pay attention to the semantic, the style and the linguistic structures of the text. On the other hand, the recent works on Lord Jim show a renewed interest in this text and the other works by Conrad as having influences on the Twenty-first Century. Many of 
such critics hold a general belief that Conrad is one of the precursors to postmodernism. This does not, however dissuade some critics in the twenty-first century from reading the texts as the testimony on the lives of the authors and societies as several critics take a postcolonial approach to their readings while very few critics give attention to sexuality in the novels. 


\section{Works Cited}

Acheraïou, Amar. Joseph Conrad and the Reader: Questioning Modern Theories of Narrative and Readership. Macmillan-Palgrave, 2009.

Chandler, James. 'On the Face of the Case: Conrad, Lord Jim, and the Sentimental Novel.' Critical Inquiry, Vol. 33, No. 4, Summer 2007, pp. 837-864 JSTOR, www.jstor.org/stable/10.1086/521572

Condon, G. Mathew. 'The Cost of Redemption in Conrad's Lord Jim.' Literature and Theology, Vol. 12 No. 2, June 1998, pp. 135-148. JSTOR, Www.jstor.org/stable/23926274

Conrad, Joseph. Lord Jim. Doubleday and Company, 1961.

Dodson, Sandra. 'Conrad's Lord Jim and the Inauguration of a Modern Sublime.'The Conradian, Vol. 18, No. 2, Autumn 1994, pp. 77-101. JSTOR, www.jstor.org/stable/20874058

Epstein, S. Harry. 'Lord Jim as a Tragic Action.' Studies in the Novel, Vol. 5, No. 2,Summer 1973, pp. 229-247. JSTOR，www.jstor.org/stable/29531593

Glenny, Rachel. 'Impressions of Joseph Conrad's Lord Jim. 'The Journal of the Joseph Conrad Society, Vol. 2, No. 3, March 1976, pp. 9-11. JSTOR, www.jstor.org/stable/20870454

Hampson, Robert. Cross-Cultural Encounters in Joseph Conrad's Malay Fiction. MacmillanPalgrave, 2000.

---. Joseph Conrad: Language and Fictional Self-Consciousness. Edward Arnold, 1979.

Hawthorn, Jeremy. Sexuality and the Erotic in the Fiction of Joseph Conrad. Continuum, 2007.

Kerr, Douglas. 'Crowds, Colonialism, and Lord Jim.'The Conradian, Vol. 18, No. 2, Autumn 1994, pp. 49-64. JSTOR, www.jstor.org/stable/20874056 
Krishnan, Sanjay.'Seeing the Animal: Colonial Space and Movement in Joseph Conrad's Lord Jim.’ NOVEL: A Forum on Fiction, Vol. 37, No. 3, Summer 2004, pp. 326-351. JSTOR, www.jstor.org/stable/40267598

Levin, Yael. Tracing the Aesthetic Principle in Conrad's Novels. Macmillan-Palgrave, 2008. Mongia, Padmini. 'Narrative Strategy and Imperialism Conrad's Lord Jim. 'Studies in the Novel, Vol. 24, No. 2, Summer 1992, pp. 173-186. JSTOR, www.jstor.org/stable/29532856

Raval, Suresh. 'On Reading Conrad. 'Studies in the Novel, Vol. 13, No. 4, Winter 1981, pp. 439-448 JSTOR, www.jstor.org/stable/29532128

Seeley, Tracy. 'Conrad's Modernist Romance: Lord Jim.' ELH, Vol. 59, No. 2, Summer 1992, pp. 495-511. JSTOR, www.jstor.org/stable/2873352

Sherry, Norman. 'Conrad's Source for Lord Jim. 'The Modern Language Review, Vol. 59, No. 4, Oct. 1964. JSTOR, www.jstor.org/stable/3721030

Sullivan II, Ernest W. 'Lord Jim's “Reward”: An Allusion to The Tempest. 'The Conradian, Vol. 7, No. 2, August 1982. pp. 27-28. JSTOR, www.jstor.org/stable/20873776

Taylor, Craig. 'Literature, Moral Reflection and Ambiguity. 'Philosophy, Vol. 86, No. 335, Jan. 2011. pp. 75-93. JSTOR, www.jstor.org/stable/23014771

Trogdon, Robert W. R. Dos Passos and Jr. 'John Dos Passos on Lord Jim. 'The Conradian, Vol. 25, No. 1, spring 2000. pp. 99-103. JSTOR, www.jstor.org/stable/20874167 Wheeler, Marcus. 'Polonisms in Conrad's Lord Jim. 'The Journal of the Joseph Conrad Society, Vol. 2, No. 3, March 1976, pp.6-8. JSTOR, www.jstor.org/stable/20870452 